\author{
Nataliia Morze \\ Doctor of Pedagogical Sciences, Professor, Corresponding Member of National Academy of Pedagogical \\ Sciences of Ukraine \\ Vice-Rector on Informational Technologies Borys Grinchenko Kyiv University, Kyiv, Ukraine \\ n.morze@kubg.edu.ua \\ ORCID: 0000-0003-3477-9254
}

\title{
Ewa Ogrodzka-Mazur
}

Prof. Ph.D. hab.

University of Silesia in Katowice, Faculty of Ethnology and Educational Science in Cieszyn, Poland

eom1@wp.eu

ORCID: 0000-0001-9990-6176

\section{Paulo Pinto}

$\mathrm{PhD}$, Auxiliary Professor of Faculty of Economy and Enterprise Sciences

The Lisbon Lusíada University, Lisboa, Portugal

pjpinto@lis.ulusiada.pt

ORCID: 0000-0002-0675-6293

\section{Olena Glazunova}

Doctor of pedagogical sciences, associate professor, dean of faculty of information technologies National University of Life and Environmental Sciences of Ukraine, Kyiv, Ukraine

o-glazunova@nubip.edu.ua

ORCID: 0000-0002-0136-4936

\section{Josef Malach}

PhDr. PhD

Head of the Department of Education and Adult Education

Pedagogical Faculty, University of Ostrava, Ostrava, Czech Republic

josef.malach@ozu.cz

\section{Valeria Zabolotna}

Director for organizational development of investment and development company UDP,

Program manager K.FUND, Head of UNIT Factory, Kyiv, Ukraine

\section{Nadiia Balyk}

$\mathrm{PhD}$ in Pedagogy, Assosiate Professor

Volodymyr Hnatiuk Ternopil National Pedagogical University, Ternopil, Ukraine

nadbal@fizmat.tnpu.edu.ua

ORCID: 0000-0002-3121-7005

\section{EDUCATIONAL E-ENVIRONMENT OF MODERN UNIVERSITY: FOREIGN EXPERTS' PERSPECTIVE}

\begin{abstract}
The article considered issues of the third international conference "Open educational eenvironment of modern university" with the participation of international experts. Group of European and Ukrainian experts discussed problems of the open and closed educational environment, shared their professional experience of development universities' openness in the age of modern technologies.
\end{abstract}

Keywords: discussion; e-environment; open; university; experience; educational

The development of modern technologies and tools naturally influences on educational environment. In the Informational Age, modern society can't be closed toward information and this openness naturally reflects in education, which represents social and economic relations in society. Education should answer actual society needs and requests. Open education is one of the newest forms of the social development. It provides the 
implementation of new information and pedagogical technologies in teaching process. However, the forms of knowledge acquisition and update have remained unchanged.

The ways of solving these problems are:

- Creating of global educational and informational environment;

- Using of open education;

- Providing an open access to distributed information and technological resources;

- Knowledge management has become a new educational principle.

And at the same time equal access to knowledge, knowledge transmission and distribution, knowledge control have become new technologies of education, should be provided at all levels of education system. All this questions were discussed during the third conference "Open educational e-environment of modern university". Group of International and Ukrainian experts, sciences and teachers shares their professional and personal experience of the development of open educational environments in the Information Age.

The discussion was moderated by Prof. Nataliia Morze, Doc. Hab. Of Pedagogy, Vice rector of Borys Grinchenko Kyiv University, Ukraine.

The group of experts:

- Ewa Ogrodzka-Mazur, Prof. Ph.D. hab., University of Silesia, Cieszyn, Poland;

- Paulo Pinto, PhD, Auxiliary Professor, The Lisbon Lusíada University, Lisboa, Portugal;

- Olena Glazunova, doctor of pedagogical sciences, associate professor, National University of Life and Environmental Sciences of Ukraine, Ukraine;

- Josef Malach, PhDr. PhD, University of Ostrava, Ostrava, Czech Republic;

- Valeria Zabolotna, Director for organizational development of investment and development company UDP, Program manager K.FUND, Head of UNIT Factory, Ukraine;

- Nadiia Balyk, PhD in Pedagogy, Assosiate Professor, Volodymyr Hnatiuk Ternopil National Pedagogical University, Ukraine.

Nataliia Morze, Ukraine: What university environment can be called open? And closed? What and who should open universities?

Ewa Ogrodzka-Mazur, Poland: A similar situation is in Poland. We have a certain standard - the Polish standard is to be the open university. This results from European standards concerning Open University. In my university, we have $40 \%$ of e-learning classes and $60 \%$ regular classes. For twenty years, we have been becoming open university step by step. But it is still an important question - Is it already open university or not yet if we compare it to West European universities?

Paulo Pinto, Portugal: It is not an easy question to answer, because, as far as I have seen, during this project, we have some differences in every country. The teaching, the goals are different. The main goal is to teach students. What is to be open? We have progressing in the way of teaching, during times. Today, we have whole new world of technologies that allow us to go out teaching class.

So the question is - is university open? It is the question which goes together with another one - Are the teachers ready to be open? It isn't done in single step. It is done step by step.

In my University we started very slow in it. First place we were given students more information available. Instead of going to the secretary or filling papers and asking for the information we give this information in the e-way.

The second step we move forward - The students can interrupt forward and can make the requirements in the administrative way. On the other hand, teachers have given e-learning management system, like Moodle - it is Moodle. So, they start put materials on Moodle. Now 
we are ready to go out of the physical building of the University and starting on-line courses. Still, I don't know, if we have got an open University. Thank You.

Olena Glazunova, Ukraine: Educational and scientific resources, which are placed in the e-environment of the University, should find their user. That is why I would like to go back to the issue of what and whom the Universities have to open. When it comes to the issue of "whom", then Universities have to open their resources, in the first place, to their students, lecturers and the University staff. Access to such resources may be authorized. National University of Life and Environmental Sciences of Ukraine opens the e-environment partly to the students and lecturers of the University, and partly - to the global community. For example, as many Universities in Europe, it uses CLMS Moodle for providing the students and lecturers with electronic learning courses, which are available after the corresponding registration at the portal and at the course. At the same time, a substantial part of other eenvironment resources is open without any restrictions to the global community. In particular, these are the resources that demonstrate the scientific potential, possibilities of the University, that are supposed to be open for everyone who wants to study the relevant experience, to get acquainted with researches and publications online; the examples are institutional repositories, electronic libraries, sites of electronic journals, scientific conferences, etc.

Josef Malach, Czech Republic: In the Czech Republic, there are 4 main directions in opening and development of the Universities. The first direction is the massification of education. About $70 \%$ of graduates enter Universities. And now we have specialization and focused specialization of programs and training courses. And at the same time, we do not have enough financial resources to carry out this process effectively. Probably the fourth direction is to improve of quality of education and quality management of universities. These areas cause certain problems that may affect the effective use of open learning and e-learning.

We can say that we are good at e-government, e-management, and such principles. We have very well developed documentation and support for accreditation, licensing of training programs. We also have excellent students' testing, especially if this is students' mobility, when the certification takes place in various subjects.

But when we talk about e-learning, the lack of financial resources affects the fact that only some departments can create e-learning courses. Therefore, it is important for us that we involve the resources of the European Union via our job. Financing stopped last year, and now we do not have enough resources for our projects.

We have a lot of humanitarian subjects, and when we talk about such subjects as pedagogy, psychology, sociology, there are not many electronic courses in order to teach them, so a lot of resources are spent on preparing courses not in pedagogical direction. We are very glad that within the framework of this project we are able to prepare courses for the pedagogical sector and educators. And we hope that this conference will be very fruitful for everybody who takes part in the conference.

Valeria Zabolotna, Ukraine: I would like to share with you, perhaps, more revolutionary approach in education, although I represent traditional academic education at the classical university, and more innovative way of teaching.

As we live in a constantly changing, dynamic, environment, I think that the issue of closeness - is a big question, if you can say so. If the textbook gets into the hands of our students - it becomes electronic.

The approach that I have mentioned is revolutionary approach that allows students to intensify their cognitive activity due to the lack of teachers. This establishment works $7 / 24$, has no charts, so students can visit the institution time when they are at the peak of performance. They receive the task via internet, at certain time, and they have to deliver them at certain time via e-net. They have few methodical materials and lectures and video materials. The way they reach the results, the way they find the answers is their own activity. 
Of course, the question arises if there are no lecturers - how to check progress? Progress is measured in two ways: automatically through different program and peer-to-peer evaluation.

Of course, the entire program is in the intranet, it is closed. However, as I have said, everything that falls into the hands of students, it is instantly appear on the Internet. We are not afraid of this, and we know that the program is built by highly skilled professors, it is done very wisely, it can't be repeated simply by taking it from the Internet.

So, we are such a closed-open institution that really gives high results.

Nadiia Balyk, Ukraine: I represent Ternopil Pedagogical University and I can say that our university is one of the pioneers in the field of e-learning. After years of working I can state that the University has created an extremely powerful modern infrastructure, which became the basis for the organization of the open environment.

The university has organized a model of mixed learning as well as a model of distance learning. In practice, $80-90 \%$ of our courses are in the Moodle system, which is used appropriately in the learning process. But still I would like to talk about the innovations that are taking place at the university regarding the theme of today's conference and about the openness of the universities. Our step to university's openness was in that we all went beyond the university's building and invited partners to the educational process. For example, such partners as the city council, the regional council, are various non-governmental organizations.

During the learning process, students have done different projects, cases and portfolios which are open to anyone who need them. We have a number of practical projects, different platforms, such as digital repositories, wikis, and all other platforms or technologies that are related to Web 2.0 that can be used by either teachers, students or representatives various nongovernmental organizations that needed to resolve certain problems. All this is in electronic form and it is open to everyone. In my opinion, this is an obvious sign of openness that not only the university community, but the whole society has access to these developments.

In conclusion, perhaps today, one should not say that the university can be closed, because the challenge is given to us by a society that is open to all formations, and through this the university as a part of a society that represents a certain sphere of scientific interests, education, should also support these high standards of openness.

Nataliia Morze, Ukraine: If the open resource is trustworthy and, vice versa, if a qualitative resource should be open still remains disputable?

Olena Glazunova, Ukraine: If a lecturer creates an open resource it means that he or she has no doubt as for the quality of it, but still the qualification of such a lecturer may be put to question. Another aspect is his/her motivation. A qualitative learning resource may be created for sharing with others. It happens because you can make money on it. That is why not all the qualitative resources are at free access, as well as not all open resources are qualitative. Another thing is when the University opens e-environment resources, which passed the procedure of quality evaluation, that includes subject-oriented, scientific-andcomprehensive, methodic and functional expertise of learning resources.

Nataliia Morze, Ukraine: Who has to decide which resources should be open and which - should not?

Olena Glazunova, Ukraine: E-environment has to be administered in line with certain statutory documents, which are to be approved by the Academic Council, Research and Methodology Council etc. The example of the National University of Life and Environmental Sciences of Ukraine testifies to the efficacy of using special procedures of e-environment management, which are developed on the basis of quality management standard ISO9001. These procedures determine the principles of e-environment platform functioning, as well as resources that should be open, close, and the ones that should have the authorized access. 
Nataliia Morze, Ukraine: Does the quality of education influence the openness of a university e-environment (\%)? Supply an example, please

Ewa Ogrodzka-Mazur, Poland: I am a very old academic teacher. I remember the times when university was closed to new technologies. These days, I think, it is impossible to close university to new technologies. It's a very important question for me. In humanities and social sciences, the direct contact with students is crucial. For example, In my teacher's work I need normal contacts with my students to get information how they speak, interact, take part in group discussion, work in a team. I think, this is not included in e-learning courses. The quality of education and of educational system depends on how teachers think about distance learning and how they engage in it.

Paulo Pinto, Portugal: I think these two things may not be correlated. Because, quality it is the thing we always have present, whether the environment is open or closed. But I believe, that open environment can lead to better quality, because, the student can actually choose from anyone in the world to teach him. So, he is going to choose the better, and it's going generally better. It is very short.

Nataliia Morze, Ukraine: Dear experts and participants of the conference! I appeal now to all of You with such question as deja vu: wouldn't You have such feeling when your children or you - yourselves have prepared something very good - it can be a presentation, some of Your own job, or a book. And you really want to show it to everybody, to share with everybody, to show to the whole world. Because you have put there your efforts, your thoughts, your mind and You have such feeling - You want to give everything, because you will make another one.

I'll ask in another way, when You do your job in an excellent (quality) way, competence. You want to open it to the whole world using technologies. Share, please, yes or not, or how these things can be correlating? Thank You very much.

Nataliia Morze, Ukraine: Sometimes, some universities or departments, or teachers say, "I don't give my own," don't You have the impression, that they hide because it can't be on a certain level. And the most important, teacher understands it?

Ewa Ogrodzka-Mazur, Poland: I think, we have a problem with this. I agree that students must use internet sources in their work. But in Poland, for example, many students do not work on their own, do not read obligatory literature but just use ready-made "works". This is a serious problem in Poland, but I can guess it happens worldwide.

Paulo Pinto, Portugal: I think the problem is general: When you produce some good material, it is good to think: "The students will use it". But there is the problem of using internet in examination and so on. We, also, have that - we have to block the internet in the classrooms and so on.

Because in the perfect world, which we are not. In the perfect world people want to learn, go meet the people where they something to teach. But perfect world is paradise, and we are not there yet.

So, we have problems controlling these kinds of situations. But, I believe in the future with self learning and self assessment people will become more responsible.

And in the future, perhaps, us teachers can be good teachers, good resources and still good students.

Valeria Zabolotna, Ukraine: Well, of course, when you do a good job, you begin to tell everyone about it and it's difficult to stop you. This also applies to children - because I have three sons - if they do something qualitatively, then you will hear about it at least twenty times and all relatives will hear about it. And if you do something qualitatively, then all your friends hear about it. When you meet someone, first time, you recommend something - look, you can read it or you can see it, or I invite you to listen. Of course, qualitative work needs publicity. As a psychologist, I can say that when you shared with something, as Mrs. Natalia 
mentioned, you "close" Gestalt and you go further and you can develop something qualitative further.

Nataliia Morze, Ukraine: Sometimes, when some universities, or departments, or teachers say: "I will not share and show my job", then don't you start thinking that they tell it because it may not be at the appropriate level and, most importantly, the teacher understands this?

Olena Glazunova, Ukraine: If You don't mind I'll tell few words. There can be different types of works. For example, if this is the job you really want to share and you do not want to earn money from it, this is one thing, but there's still this financial aspect. When person discovered something new, something that can bring her money, of course, it is another question.

Nadiia Balyk, Ukraine: I can give you an example. I never thought a few years ago that I would use social networks, as an instrument for sharing the results of the educational process, the scientific one. In particular, I can give an example that we had a course at the University of "3D-modeling and 3D-printing" and our first very old Ternopil castle, which we printed on the city day, and of course, we wanted to show everyone that we did not just modeling something, but that this is concrete result of our job and it is an exhibit that is shown to the visitors, tourists of the city, and this is a further extension of this project. The social network is probably the most unexpected item which I use, as rather conservative person.

Josef Malach, Czech Republic: There is such problem that when we talk about pedagogy, we mentioned three main tasks: to train students, improve their skills and experience. Therefore, there are just few researches about the different using of platforms, programs and tools for e-learning courses in pedagogy, and now we are assessing how this can be used and conducting a quality assessment and combination of quality in pedagogy, if we are talking about an open environment.

Ewa Ogrodska-Mazur, Poland: One of the problems in Poland is that students do not work individually, but it is very easy for them to buy some work or some kind of report as seminar, dissertation, and other scientific works. There is a big problem of plagiarism, so we have rather different approach, we are very attentive to the use of these resources.

Paulo Pinto, Portugal: I can say, of cause: "If you do something good, you want to share with the whole world"? But when we have problems during the tests, students use the Internet and we block the system so that they don't have access to the Internet. I think this is common problem for everyone.

In the ideal world, those people who wants to study go and find those people who can teach them something. But we are not in the ideal world, because it is called paradise, and we need to be in reality. We have problem - how to control e-learning, electronic courses, but I believe that in the future there will be a higher level of self-esteem and self-development, so people will have another motivation to develop. And we can say that in the future teachers will be good teachers, good researchers and good students.

Nataliia Morze, Ukraine: Who's responsible for an e-environment openness?

Ewa Ogrodzka-Mazur, Poland: In Poland, in my university, we have people who are responsible for this. But, I think like Paulo, that every academic teachers and every student should be responsible for this openness.

Paulo Pinto, Portugal: Answer is very simple: everybody and nobody in particular, but everybody in general.

Josef Malach, Czech Republic: I have the same answers as my colleagues from Poland.

Olena Glazunova, Ukraine: On the example of our university, I have to say that these are special environmental management procedures that determine which resources are open, 
and which are not approved by the academic council of the university - this is a collective decision.

Valeria Zabolotna, Ukraine: Students are responsible for their education, and what they take by themselves - they take it with full responsibility. Although, they are not willing to take responsibility and often run to us how to do something. We have special staff responsible for quality of the program and the quality of the materials.

I agree with my colleagues. Short answer is - everybody. Speaking about - first responsibility lies with the leadership of the university, the administration, then the teachers, the students who together create the environment of the university community, live community.

Nataliia Morze, Ukraine: How much does transparency affect the quality of education in an institution?

Olena Glazunova, Ukraine: It's difficult to say a percentage, one hundred percent, because if the resource is open, it means that we are not afraid of its quality.

Nataliia Morze, Ukraine: Approximately: five, two, three, ten, ninety percent? Your feeling ... Because there became more and more fans of e-learning and openness at the university.

Nadiia Balyk, Ukraine: We can say that this is more than half the quality of success if the teacher and student ready to present their job to the whole world. This is more than half. This is a precedent.

Nataliia Morze, Ukraine: More than half? I agree that openness directly affects quality and then it turns out that when we open it, we are already trying to make quality things in order to show it to the whole world.

Valeria Zabolotna, Ukraine: I think ... I, maybe, will say something not usual, like nonsense - it seems to me that they do not correlate, these two concepts (openness and quality). Openness, potentially, can lead to high-quality of the education. Closeness does not give an opportunity for any education at all. But a good result depends from many factors.

Paulo Pinto, Portugal: I do not think there is a correlation between the quality of education and the openness of universities, because quality - it exists by itself if the university is open or closed, but nevertheless, if there is openness of the university, it potentially enables us to use the best resources which leads to the education of better quality. Thank you, it's briefly.

Ewa Ogrodska-Mazur, Poland: I'm sorry, I have a lot of experience and I remember the times when the university was completely closed and there were no technologies. Now, I believe, when there are new technologies available, closed university can't exist. But, which question is very important, for me as for typical teacher, the question of the constant contact with the student. I have to know the information my students think, but it does not necessary to involve some on-line courses. The quality of education can be influenced by attitude of the teacher to open courses or on-line courses. Thank you.

Josef Malach, Czech Republic: There are two questions here. The first question is that when students use electronic technologies, they should lose skills in dealing with sources such as books and information that is not electronic. Very often students can get competencies with IC technologies, but lose their professional competencies. Therefore, there are two sides of one problem. Not always openness is related to quality. 